\title{
Changes in the filtration function of the spleen after surgery following traumatic organ injuries
}

\author{
I. V. Kolosovych, I. V. Hanol \\ Bogomolets National Medical University, Kyiv
}

\Ihor Hanol: ganoli@ukr.net

I.V. Kolosovych, ScD, MD, Prof., Head of the Department of Surgery N2, http://orcid.org/0000-0002-2031-4897

I.V. Hanol, PhD, MD, Associate Professor of the Department of Surgery N2, http://orcid.org/0000-0002-3470-2102

The incidence of splenic injuries among all closed injuries of the abdominal cavity is from 15.5 to $30.0 \%$, and a mortality rate is between $7 \%$ and $26 \%$. The tactics in the treatment of splenic injuries is determined by the degree of traumatic injury, the patient's condition during the operation, and a concomitant pathology. Studies of tissue regeneration of the operated spleen allow identifying two main options for its regeneration, associated with the nature of blood circulation in the preserved part.

Овјестіve - to study the regeneration and filtration function of the spleen after various types of surgery for the management of traumatic spleen injuries.

Materials ANd Methods. The results of treatment of 85 patients in the period 2015-2020 were analyzed. To investigate the changes in the filtration function of the spleen, a study of the peripheral blood (general blood test) was performed to assess the shape of erythrocytes. In order to determine the size of the residual splenic parenchyma, its structure and regenerative processes were evaluated and sonographic examination was carried out.

RESUlts. The average increase in the size of the residual splenic tissue after subtotal resection of the organ with the formation of couplings of the parenchyma averages $40.2 \pm 3.4 \%$ one year after surgery, and in patients who underwent subtotal resection of the spleen with covering the cut plane with adhesive hemostatic plate $70 \%-$ $49.14 \pm 6.77 \%$. The study of changes in the filtration function of the spleen in patients, who underwent subtotal resection of the spleen, showed the appearance of target cells, acanthocytes and halocytes in the peripheral blood, but their number was insignificant and did not exceed normal (not more than $3 \%$ ). Any destroyed and pathologically altered erythrocytes were not visualized in patients, who underwent atypical resection of the spleen (mass deficit less than $30 \%$ ).

Conclusions. Spleen regeneration is determined both by the nature of blood supply to the residual splenic tissue and its size, and does not depend on the nature of the pathological process. Organ-preserving surgical interventions on the spleen allow maintaining the filtration function of the spleen.

\section{KEYwORDS}

spleen damage, organ-preserving surgical interventions, splenectomy, filtration function, regeneration.

ARTICLE • Received 2021-11-16 • Received in revised form 2021-11-24

(C) General Surgery, 2021

The spleen is an unpaired peripheral organ of lymphoid hematopoiesis and immune defense. Currently, one of the urgent problems of surgery is control of bleeding caused by the damage to the parenchymal organs of the abdominal cavity associated with injuries resulting from home-related and traffic accidents, natural disasters and terrorist acts. These conditions, based on the data from the World Health Organization studies conducted in cooperation with the Harvard Center for Prospective Studies, are a common cause of death among people of working age. The incidence of splenic injuries among all closed injuries of the abdominal cavity is from 15,5 to $30 \%$, and a mortality rate is between $7 \%$ and $26 \%$. [1]. Traumatic injuries occur in all age groups, but the peak incidence is observed in adolescence and in the middle age group (15-35 years) [2], which emphasizes the socio-economic importance of the problem.

The tactics in the treatment of splenic injuries is determined by the degree of traumatic injury, the patient's condition during the operation, and 
a concomitant pathology. To date, the most common method of treating splenic injuries has been surgery [3]. In about $99 \%$ of adult patients, the spleen was completely removed. However, this surgery can lead to severe complications, both in the early and long postoperative periods, resulting from impaired immunological homeostasis and is called «postsplenectomy hyposplenism», an extremely severe form of which is instantaneous sepsis [4].

In-depth experimental and clinical studies of tissue regeneration of the operated spleen, allow us to identify two main options for its regeneration, related to the nature of blood circulation in the preserved part. The first option is typical for organsaving interventions, when the organ or its part has a preserved main blood supply. The spleen in the postoperative period has a characteristic histological structure with the presence of elements of both red and white pulp. Computed tomography (CT) examination (including after intravenous amplification) reveals normal densitometric characteristics of organ tissue. $\gamma$-Scintigraphy with labeled autologous erythrocytes, damaged by heat, shows a sufficient accumulation of radiotherapy in the pulp of the spleen (preserved filtration function) [5].

The second type of regeneration is described in humans with free heterotopic autotransplantation of the spleen [6]. The slow regeneration of the structures of the spleen pulp is typical and associated with the germination of capillaries from the surrounding tissues, developing reticular tissue filled with erythrocytes (analog of red pulp), elements of white pulp are absent or weak [7]. Densitometric analysis of CT reveals a decrease in the density of transferred and newly formed tissue with a weak accumulation of contrast after its intravenous administration [8]. The accumulation of radiotherapy in $\gamma$-scintigraphy is observed in the projection of the graft only in the remote postoperative period. The features of the autotransplanted spleen tissue in adults are the following [9].

\section{The main anatomical changes}

1. Reduced weight ( $<20 \%$ of normal).

2. Decrease in the number of cells in a gram of tissue.

3. Decreased blood flow ( $<10 \%$ of normal).

\section{Architectural changes}

1. Structures that are in the normal spleen, but changed in the graft:

- relatively reduced area of trabeculae, marginal zone, marginal sinus, PALS (periarterial lymphocyte clusters), PALS reticulum, separation of red and white pulp;

- relatively increased area of the capsule, red pulp, increased hematopoiesis.
2. Structures that are absent in the normal spleen, but are in the graft:

- fibrous tissue;

- adipocytes in the central zone;

- location of white pulp directly under the capsule;

- accumulation of lymphocytes under the capsule;

- some proteins.

III. Functional changes: reduced filtration function, clearance, malaria protection and overwhelming post-splenectomy infection.

Negative factors include inflammatory complications after autotransplantation, which in emergency and purulent surgery can reach $30 \%$ with extraperitoneal location of fragments of the spleen [10]. Based on the described patterns, we can expect a better functional result while preserving the organ or a part of it along with the main blood supply. This is confirmed by many reports, according to which autotransplantation of the spleen is accompanied by less pronounced immunohematological changes, compared with splenectomy, but is inferior to organ-sparing operations [11]. At the same time, according to the literature, removal of $90 \%$ of the spleen does not lead to the development of hyposplenism [12]. The presented data significantly changed the tactics in the management of the diseases of the spleen.

Thus, the spleen is an organ endowed with important functions in the body. Splenectomy causes a number of serious disorders that have certain clinical manifestations. There are methods of clinical, laboratory and instrumental assessment of the structure and functions of the spleen, as well as hyposplenic manifestations.

Овјестіve - to study the regeneration and filtration function of the spleen after various types of surgery for the management of traumatic spleen injuries.

\section{Materials and methods}

According to the analysis of case histories, 156 patients with splenic trauma were operated at the clinic of the Department of Surgery No 2 at Bogomolets National Medical University (on the basis of the 1st and 2nd surgical departments of hospital No 4 in Kyiv) from 2015 to 2020. In order to study the condition of patients, including filtration function of the spleen, we arranged appointments with the operated patients by writing to them. Patients were invited to come to the clinic and undergo outpatient examination (laboratory and instrumental (sonographic). 85 (54.49\%) operated patients responded. The study included $61(71.76 \%)$ men and $24(28.24 \%)$ women. In terms of age distribution 


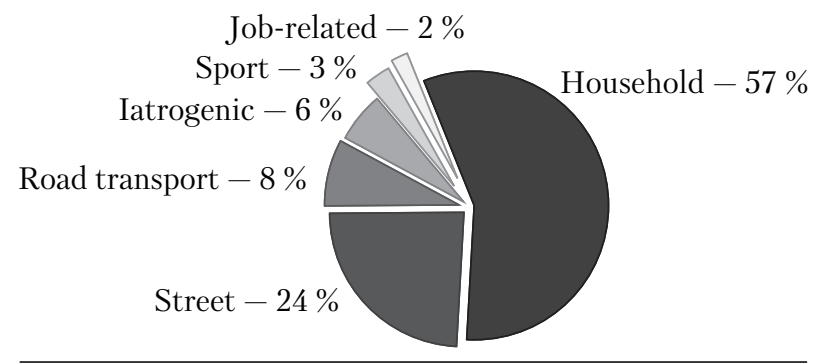

Figure 1. Distribution of patients with traumatic injuries of the spleen by the nature of the injury

of splenic injuries, the majority (30.18\%) were patients aged 20-29 years, while the average age of patients was $37.61 \pm 11.43(n=106)$, i.e. persons of working age. The causes of injury to the spleen were: a blunt trauma - 68 (80\%) cases; a knife wound $17(20 \%)$ cases. The distribution of patients by the nature of the injury is shown in Fig. 1.

Of the total number of the examined patients, $63(74.11 \%)$ patients had a history of isolated injuries of the spleen, 22 (25.89\%) were operated on for combined and multiple injuries.

According to the classification of splenic injuries proposed by the American Association of Surgical Trauma [13], 8 (9.41\%) patients were classified as splenic injuries, $18(21.18 \%)$ patients with II degree injuries, and $28(32.94 \%)$ patients with III degree, $23(27.07 \%)$ patients with IV degree and $6(7.04 \%)$ patients with $\mathrm{V}$ degree. 5 (5.88\%) patients were diagnosed with post-traumatic cyst of the spleen. Later, given the size of the residual splenic tissue, these patients were classified as patients with grade II damage to the spleen. The types of surgical interventions that were performed are presented in Table.

As can be seen from the table, a predominant number of the examined patients underwent organsaving interventions (82.3\%). However, the analysis of their case histories revealed that the proportion of patients whose spleen was removed was $36 \%$

Table. Types of surgical interventions for splenic injuries

\begin{tabular}{lc}
\hline Method of surgical intervention & Amount (n=85) \\
\hline Standard splenectomy & $15(17.7 \%)$ \\
\hline $\begin{array}{l}\text { Subtotal resection of the spleen } \\
\text { (weight deficit is more than 70\%) }\end{array}$ & $35(41.2 \%)$ \\
\hline $\begin{array}{l}\text { Atypical resection of the spleen } \\
\text { (weight deficit is less than 30\%) }\end{array}$ & $25(29.4 \%)$ \\
\hline $\begin{array}{l}\text { Minimally invasive interventions } \\
\text { (electrocoagulation, splenoraphy, } \\
\text { fenestration of the cyst) }\end{array}$ & $10(11.7 \%)$ \\
\hline
\end{tabular}

(compared to $17.7 \%$ in this study). Along with the traditional operations (cyst fenestration, electrocoagulation, splenoraphy, atypical resection of the spleen), patients underwent organ-sparing interventions, which were carried out using the methodology developed at the Department of Surgery $\mathrm{N} 2$. These were techniques that allowed to preserve part of the parenchyma in severe traumatic injuries of the organ (III-V degrees) (the method of subtotal resection of the spleen with cutting of couplings around the arteries of the second order and the method of subtotal resection of the spleen with covering the cut plane with adhesive hemostatic plate).

To study the changes in the filtration function of the spleen (mechanical blood purification function) in the early postoperative period, the peripheral blood (general blood test) was checked to detect aging, damaged erythrocytes, pathological cells (spherocytes, sickle cells, etc.), as well as assess the shape of erythrocytes. However, upon careful study of the hemogram, we found that the shape of erythrocytes also depended on the method by which blood was taken for analysis. We compared the informativeness of the methods of studying the filtration function of the spleen during the collection of venous and capillary blood.

\section{Results and discussion}

Analyzing the nature of surgical interventions, which were performed in different time periods, we can say that the concept of choosing the method of surgical intervention in patients with splenic trauma has changed dramatically. Since 2015, the organ-preserving approach has prevailed. Even in case of severe organ damage (IV-V degree), a subtotal resection of the spleen is performed. For post-traumatic cysts of the spleen, laparoscopic surgical techniques (fenestration of cysts) are most commonly used.

Ultrasound examination of the abdominal cavity allowed visualization of the residual splenic parenchyma, assessment of its structure and characteristics of the regenerative processes after the application of organ-saving techniques. The spleen, including the structure of the left parenchyma, was studied, and a doppler investigation was ordered to evaluate blood flow and verify the detected parenchymal formation. The size of the spleen stump was determined by using an associated software package after measuring its largest size in two-dimensional orientation and delineation. The sonograms, which were performed in the early postoperative period and recorded in the patient's case history, were used as a control measurement (Fig. 2). The study of the spleen in patients, who underwent subtotal 


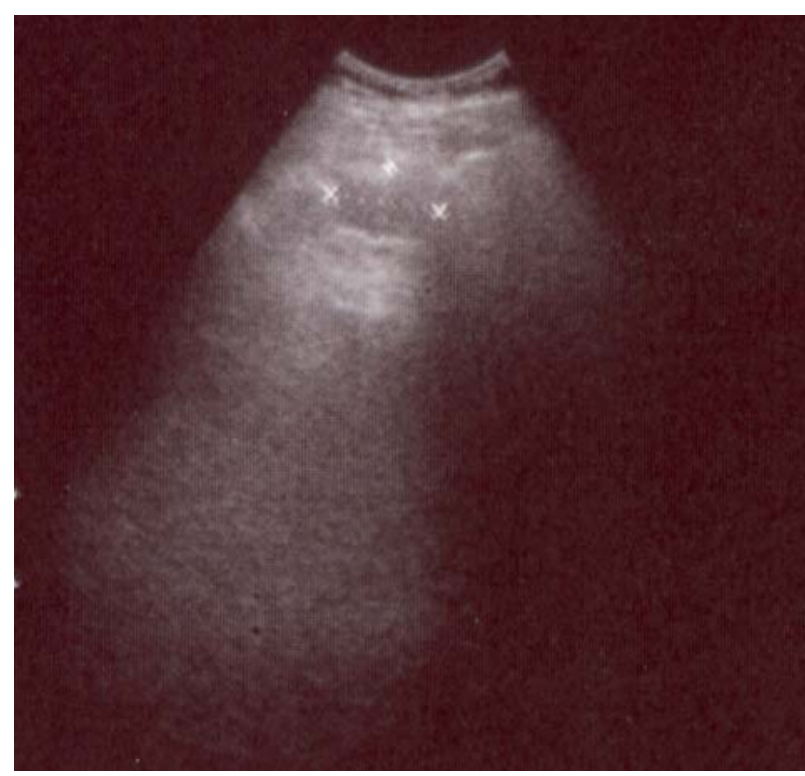

Figure 2. Ultrasound scan of the left area of the parenchyma after subtotal resection of the spleen with the formation of couplings of the parenchyma (on day 10 of the early postoperative period)

resection of the spleen with the formation of parenchymal couplings (parenchymal deficit was more than $70 \%$ ) in the remote postoperative period, revealed a decrease in heterogeneity and an increase in the size of the residual splenic parenchyma. Analyzing the obtained data, we found out that the average increase in the size of the spleen after

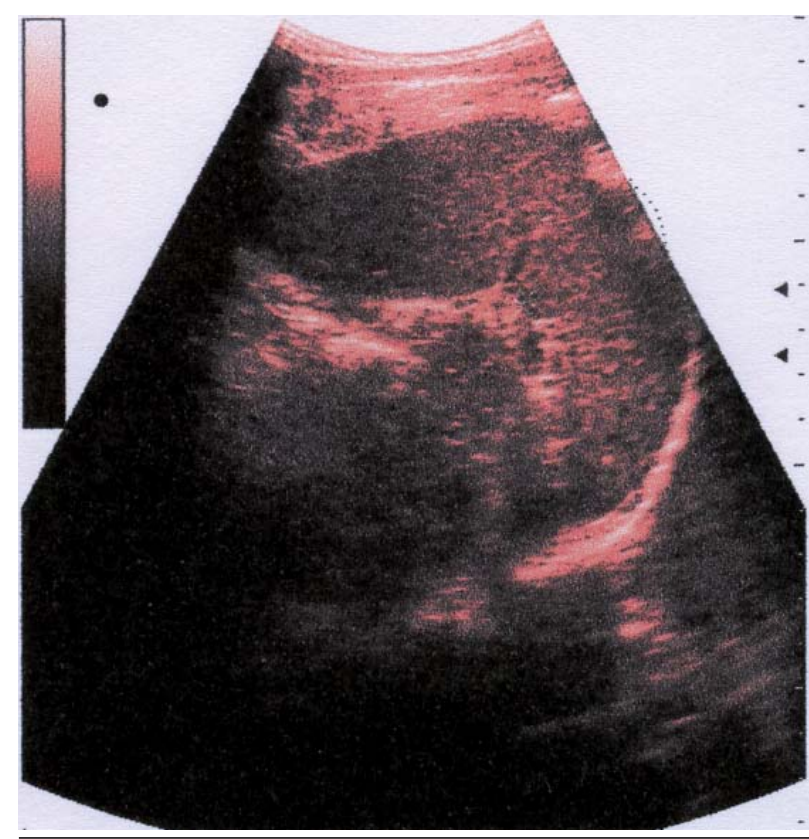

Figure 4. Ultrasound scan of the spleen after subtotal resection of the organ with covering the plane of the cut with an adhesive hemostatic plate (4 years after surgery)

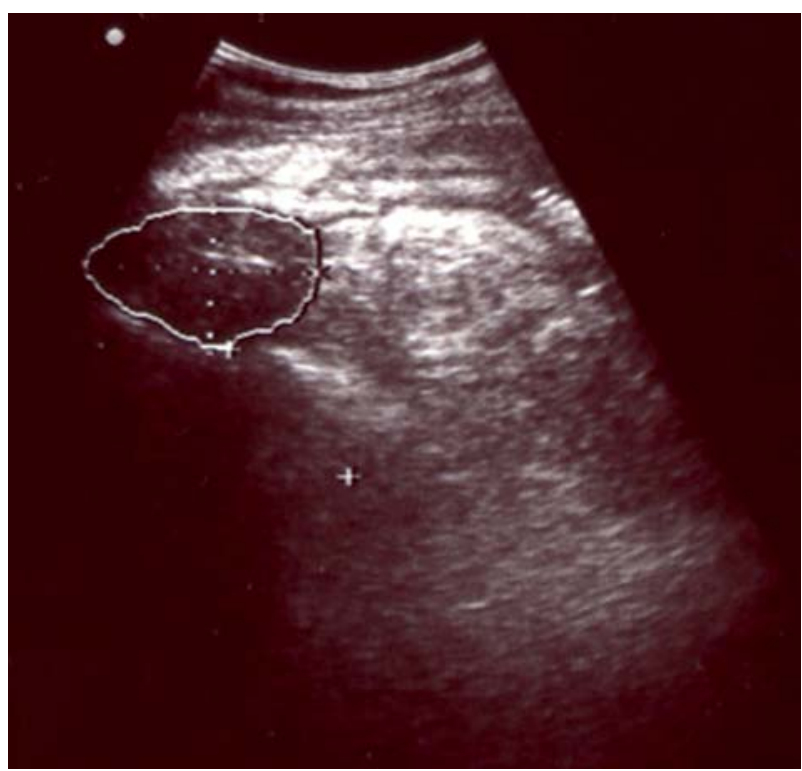

Figure 3. Ultrasound scan of the left area of the parenchyma after subtotal resection of the spleen with the formation of couplings of the parenchyma one year after surgery

subtotal resection of the organ with the formation of couplings of the parenchyma one year after surgery averages $40.2 \pm 3.4 \%$ compared to baseline. Ultrasound data of the left area of the parenchyma of the spleen two months after surgery are presented in Fig. 2 and 3.

In patients, who underwent subtotal resection of the spleen with covering the incision plane with adhesive hemostatic plate (parenchymal deficit was less than $70 \%$ ), there was a more intense increase in the size of the left parenchyma, which, in our opinion, can be associated with a larger surface area of the left parenchyma (a year after surgery, an increase in the size was $49.14 \pm 6.77 \%$ compared to baseline). In one patient, 4 years after subtotal resection of the spleen with covering the plane of the cut with an adhesive hemostatic plate, complete restoration of the structure and size of the spleen was noted (Fig. 4).

The data described above allow us to conclude that the regeneration of the spleen is determined by the nature of blood supply to the residual splenic tissue and its size, and does not depend on the nature of the pathological process.

Analyzing different ways of blood collection for the study of the filtration function of the spleen, it was found that when taking venous blood, the assessment of changes in erythrocytes can not be considered informative. This is due to the fact that according to the method, blood is taken into a test tube that contains an anticoagulant. Its components (for example, Trilon-B or citrate) affect erythrocytes, changing their shape (Fig. 5). 


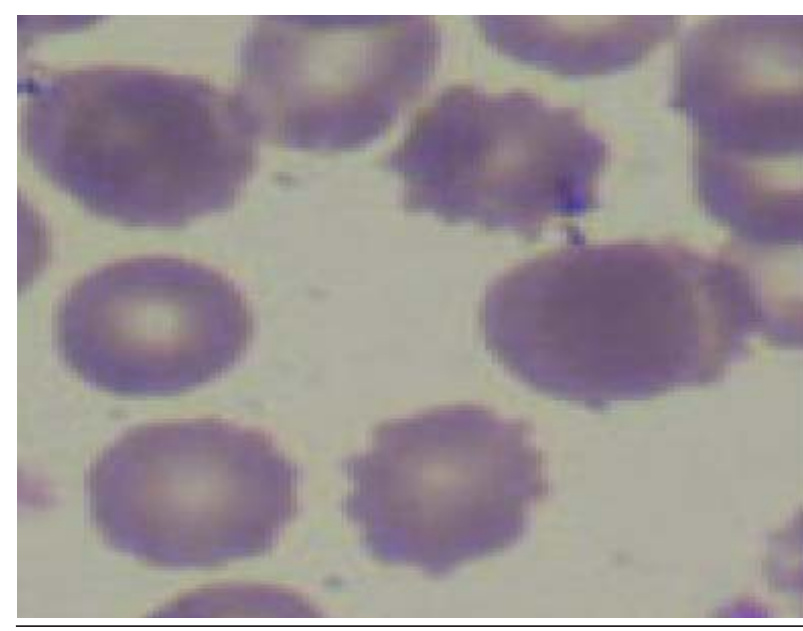

Figure 5. Examination of red blood cells in patients after organ-sparing surgery on the spleen by venous blood sampling, Pappenheim staining, lens $\times 100$, microscope Olympus CX 41 (Japan): change in the shape of erythrocytes

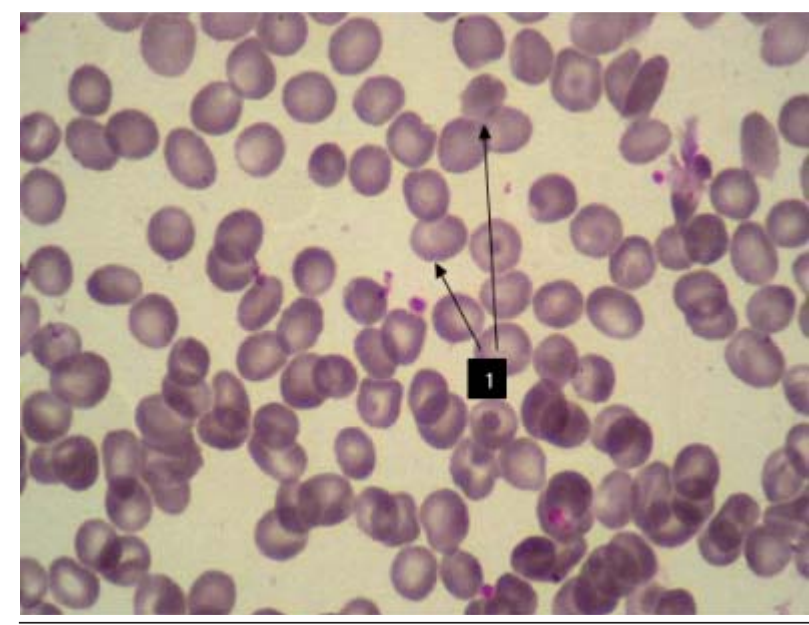

Figure 7. Examination of red blood cells in patients after subtotal resection of the spleen - a deficit of more than $\mathbf{7 0} \%$, Pappenheim staining, lens $\times 100: 1-$ single target cells

To objectively assess the changes in the hemogram in the norm and in pathological conditions, it is necessary to use a second drop of capillary blood when taking it directly from the finger on the slide (Fig. 6).

When studying changes in the filtration function of the spleen in patients who underwent subtotal resection of the spleen (mass deficit of more than $70 \%$ ), the appearance of target cells, acanthocytes and halocytes in the peripheral blood was observed, but their number was insignificant and did not exceed normal (not more than $3 \%$ ). The appearance of fragmented, damaged erythrocytes, as well as changes in the chromium of erythrocytes in the studied blood samples, was not observed (Fig. 7).

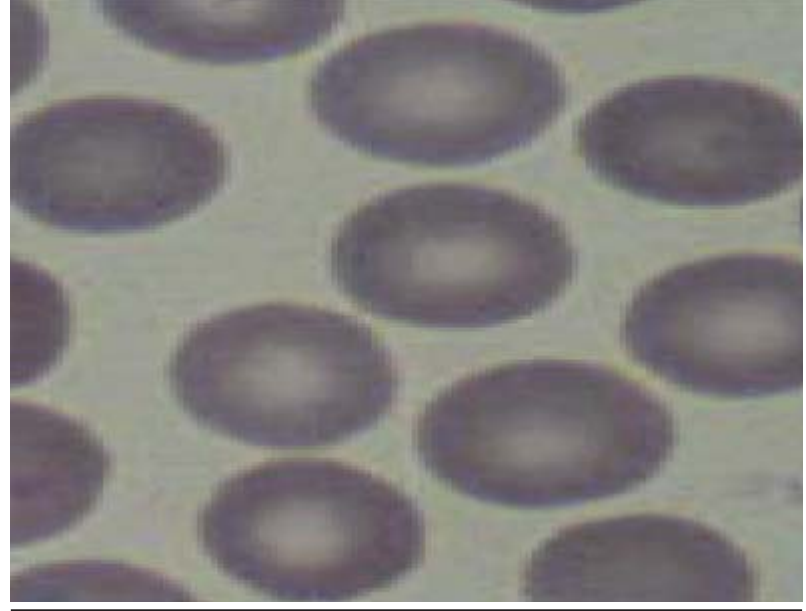

Figure 6. Examination of red blood cells in patients after organ-sparing surgery on the spleen by capillary blood collection, Pappenheim staining, lens $\times 100$, microscope Olympus CX 41 (Japan): normal erythrocytes

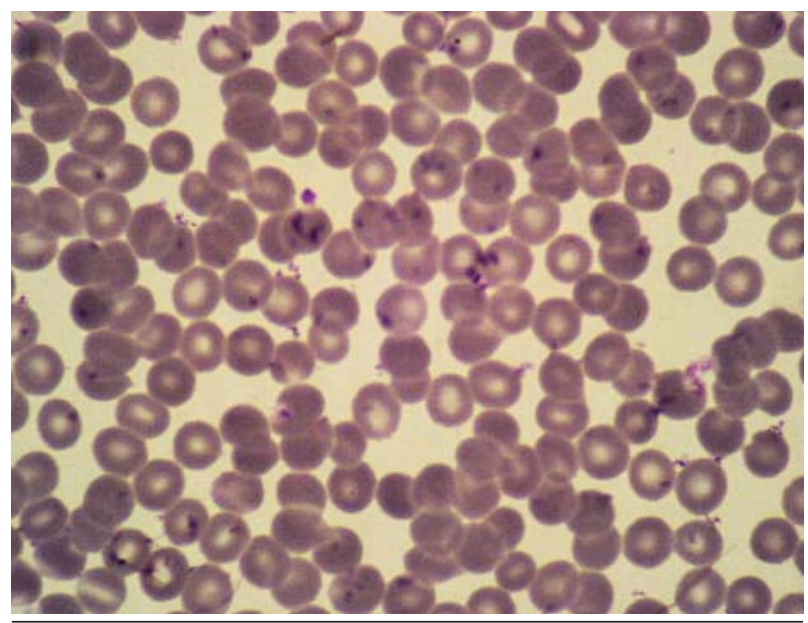

Figure 8. Examination of red blood cells in patients after atypical resection - removal of less than $30 \%$ of the parenchyma, Pappenheim staining, lens $\times 100$; pathologically altered erythrocytes were not detected

In the blood samples of patients who underwent atypical resection of the spleen (mass deficit of less than $30 \%$ ), destroyed and pathologically altered erythrocytes were not visualized or their number did not exceed normal. This fact can be explained by a larger surface area of the splenic parenchyma that is preserved during surgery and less traumatizing surgical procedure, both resulting in more efficient functioning of the left parenchyma in the postoperative period. The described data are presented in Fig. 8.

After splenectomy, a considerable impairment of the filtration function of the organ was manifested by a significant number of destroyed (fragmented) erythrocytes, pathological cells (spherocytes, sickle 


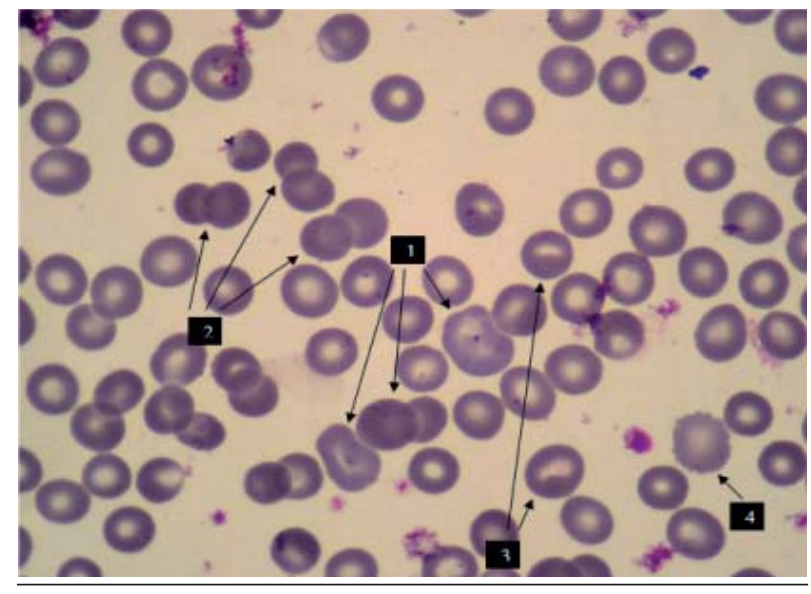

Figure 9. Examination of red blood cells in patients after splenectomy, Pappenheim staining, lens $\times 100$ : 1 - severe anisocytosis, with the presence of giant erythrocytes; 2 - erythrocyte hyperchromia; 3 - a significant number of stomatocytes; 4 - acanthocyte

cells, target cells, acanthocytes, etc.), erythrocytes with different hemoglobin size and content in peripheral blood (Fig. 9).

Thus, taking into account the described data, we can conclude that the presence of even a small amount of the splenic parenchyma and normal blood flow through it ensure maintenance of the filtration function of the organ, while removal of the spleen is associated with serious disorders of the organ. erythrocytes in excess of normal (more than $3 \%$ ).

\section{Conclusions}

Regeneration of the spleen is determined by the nature of blood supply to the residual splenic tissue and its size, and does not depend on the nature of the pathological process.

Organ-preserving surgical interventions, including subtotal resection of the organ, allow the spleen to perform its filtration function (destroyed and pathologically altered erythrocytes were not visualized or their number did not exceed normal).

Splenectomy leads to serious and persistent changes in the patient's hemogram (appearance of a significant number of destroyed (fragmented) erythrocytes, pathological cells (spherocytes, sickle cells, target cells, acanthocytes, etc. in the peripheral blood).

To objectively assess the hemogram, capillary blood sampling from a finger (the second drop is taken directly on a glass slide) must be performed.

The use of venous blood for research is uninformative due to the damaging effect of the preservative on erythrocytes.

\section{AUTHOR CONTRIBUTIONS}

I. V. Kolosovych: conception or design of the work, drafting the aricle, critical revision of the article; I. V. Hanol: data collection, data analysis and interpretation, drafting the article.

\section{DECLARATION OF INTERESTS}

The Authors declare no conflicts of interest.

Funding. The work was performed in accordance with the plan of the research work of the Department of Surgery N2 of Bogomolets National Medical University: «Development and implementation of methods for diagnosis and treatment of surgical pathology of the abdominal cavity and blood circulation». The authors did not receive any additional financial support.

\section{REFERENCES}

1. Cardoso DL, Cardoso Filho FA, Cardoso AL, Gonzaga ML, Grande AJ. Should splenic autotransplantation be considered after total splenectomy due to trauma? Rev Col Bras Cir. $2018 \mathrm{Ju}$ 10;45(3):e1850. English, Portuguese. doi: 10.1590/0100-6991e20181850. PMID: 29995152.

2. Cinquantini F, Simonini E, Di Saverio S, et al. Non-surgical Management of Blunt Splenic Trauma: A Comparative Analysis of Non-operative Management and Splenic Artery EmbolizationExperience from a European Trauma Center. Cardiovasc Intervent Radiol. 2018 Sep;41(9):1324-32. doi: 10.1007/s00270-0181953-9. Epub 2018 Apr 18. PMID: 29671059.

3. Coccolini F, Montori G, Catena F, et al. Splenic trauma: WSES classification and guidelines for adult and pediatric patients. World J Emerg Surg. 2017 Aug 18;12:40. doi: 10.1186/s13017-017-01514. PMID: 28828034; PMCID: PMC5562999.

4. Dehli T, Bågenholm A, Trasti NC, Monsen SA, Bartnes K. The treatment of spleen injuries: a retrospective study. Scand J Trauma Resusc Emerg Med. 2015 Oct 29;23:85. doi: 10.1186/s13049015-0163-6. PMID: 26514334; PMCID: PMC4625526.

5. Di Carlo I, Toro A. Splenic autotransplantation is always valid after splenectomy. J Invest Surg. 2017 Dec;30(6):401-2. doi: 10.1080/08941939.2016.1268656. Epub 2017 Jan 3. PMID: 28045550

6. El-Matbouly M, Jabbour G, El-Menyar A, Peralta R, et al. Blunt splenic trauma: Assessment, management and outcomes. Surgeon. 2016 Feb;14(1):52-8. doi: 10.1016/j.surge.2015.08.001. Epub 2015 Aug 30. PMID: 26330367

7. Frandon J, Rodiere M, Arvieux C, et al. Blunt splenic injury: are early adverse events related to trauma, nonoperative management, or surgery? Diagn Interv Radiol. 2015 Jul-Aug;21(4):327-33. doi: 10.5152/dir.2015.14800. PMID: 26081719; PMCID: PMC4498428.

8. Grunewald STF, Rezende AB, Figueiredo BBM, et al. Autotransplantation of spleen mitigates drug-induced liver damage in splenectomized mice. J Invest Surg. 2017 Dec;30(6):368-75. doi: 10.1080/08941939.2016.1255806. Epub 2016 Nov 30. PMID: 27901623.

9. Luu S, Spelman D, Woolley IJ. Post-splenectomy sepsis: preventative strategies, challenges, and solutions. Infect Drug Resist. 2019 Sep 12;12:2839-51. doi: 10.2147/IDR.S179902. PMID: 31571940; PMCID: PMC6748314.

10. Miko I, Nemeth N, Peto K, Furka A, Toth L, Furka I. Changes of red blood cell aggregation parameters in a long-term follow-up of splenectomy, spleen-autotransplantation and partial or subtotal spleen resections in a canine model. Clin Hemorheol Microcirc. 2017;67(1):91-100. doi: 10.3233/CH-170264. PMID: 28598833.

11. Olthof DC, van der Vlies CH, Goslings JC. Evidence-based management and controversies in blunt splenic trauma. Curr Trauma Rep. 2017;3(1):32-7. doi: 10.1007/s40719-017-0074-2. Epub 2017 Feb 9. PMID: 28303214; PMCID: PMC5332509.

12. Surendran A, Smith M, Houli N, Usatoff V, Spelman D, Choi J Splenic autotransplantation: a systematic review. ANZ J Surg. 2020 Apr;90(4):460-6. doi: 10.1111/ans.15383. Epub 2019 Oct 2. PMID: 31576640

13. Toro A, Parrinello NL, Schembari E, et al. Single segment of spleen autotransplantation, after splenectomy for trauma, can restore splenic functions. World J Emerg Surg. 2020 Mar 4;15(1):17. doi: 10.1186/s13017-020-00299-z. PMID: 32131858; PMCID: PMC7057566. 


\section{Зміни фільтраційної функції селезінки після оперативних втручань з приводу травматичних ушкоджень органа}

\section{І. В. Колосович, І. В. Ганоль}

Національний медичний університет імені О. О. Богомольця, Київ

Частота травматичних ушкоджень селезінки серед усіх закритих травм органів черевної порожнини становить від 15,5 до 30,0\%, летальність складає 7-26\%. Тактика і спосіб лікування визначаються ступенем травматичного ушкодження, станом хворого під час операції та наявністю супутньої патології. Дослідження регенерації тканин прооперованої селезінки дають змогу виділити два основних варіанти ii регенерації, пов'язані з характером кровообігу в збереженій частині.

Мета - вивчити регенераційну та фільтраційну функції селезінки після різних видів операцій з приводу iї пошкодження.

Матеріали та методи. Проаналізовано результати лікування 85 пацієнтів за період 2015-2020 рр. Для вивчення змін фільтраційної функції селезінки проводили дослідження периферичної крові хворих (загальний аналіз крові) 3 оцінкою форми еритроцитів. Для візуалізації залишеної частини паренхіми селезінки, оцінки ії структури та особливостей регенеративних процесів використовували сонографічне дослідження.

Результати. Середній приріст площі селезінки при застосуванні способу субтотальної резекції органа 3 формуванням муфт паренхіми через рік становив у середньому $(40,2 \pm 3,4) \%$, а у пацієнтів, яким було застосовано спосіб субтотальної резекції селезінки з укриванням площини зрізу клейовою гемостатич-

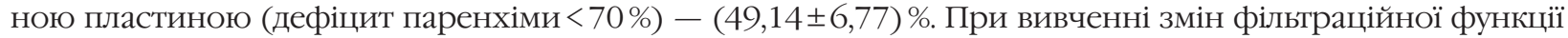
селезінки у хворих, яким була виконана субтотальна резекція селезінки, виявлено появу мішенеподібних клітин, акантоцитів і галоцитів у периферичній крові, однак їх кількість була незначною та не перевищувала показників норми (не більше 3 \%). У пацієнтів, яким була виконана атипова резекція селезінки (дефіцит маси <30\%), зруйновані та патологічно змінені еритроцити не візуалізувались.

Висновки. Регенерація селезінки визначається як характером кровопостачання тканини, що залишилася, так і ії кількістю, та не залежить від характеру патологічного процесу. Органощадні хірургічні втручання на селезінці дають їй змогу виконувати фільтраційну функцію.

Ключові слова: ушкодження селезінки, органощадні хірургічні втручання, спленектомія, фільтраційна функція, регенерація.

\section{Автори}

$\bigotimes$ Ганоль Ігор Васильович: ganoli@ukr.net

I. В. Колосович, д. мед. н., проф., зав. кафедри хірургіï № 2 https://orcid.org/0000-0002-2031-4897

I. В. Ганоль, к. мед. н., доцент кафедри хірургіi № 2, https://orcid.org/0000-0002-3470-2102

I Kolosovych IV, Hanol IV. Changes in the filtration function of the spleen after surgery following traumatic organ injuries. General Surgery (Ukraine). 2021:1;24-30. http://doi.org/10.30978/GS-2021-1-24. 